GEOLOGICAL SURVEY CIRCULAR 606

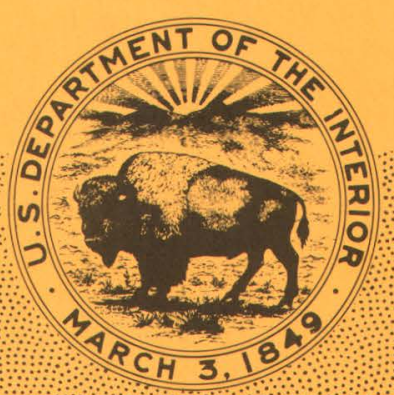

Anomalous Concentrations of Gold, Silver, and Other Metals in the Mill Canyon Area Cortez Quadrangle, Eureka and Lander Counties, Nevada 

Anomalous Concentrations of Gold, Silver, and Other Metals in the Mill Canyon Area Cortez Quadrangle, Eureka and Lander Counties,Nevada

By James E. Elliott and John D. Wells

GEOLOGICAL SURVEY CIRCULAR 606 


\section{United States Department of the Interior}

WALTER J. HICKEL, Secretary

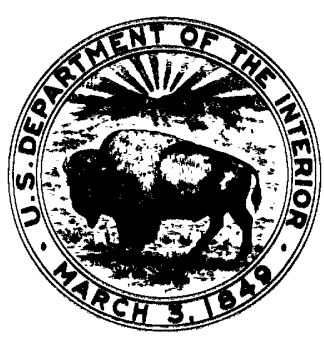

Geological Survey

William T. Pecora, Director

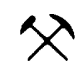

First printing 1968

Second printing 1970

Free on application to the U.S. Gealogical Survey, Washington, D.C. 20242 


\section{CONTENTS}

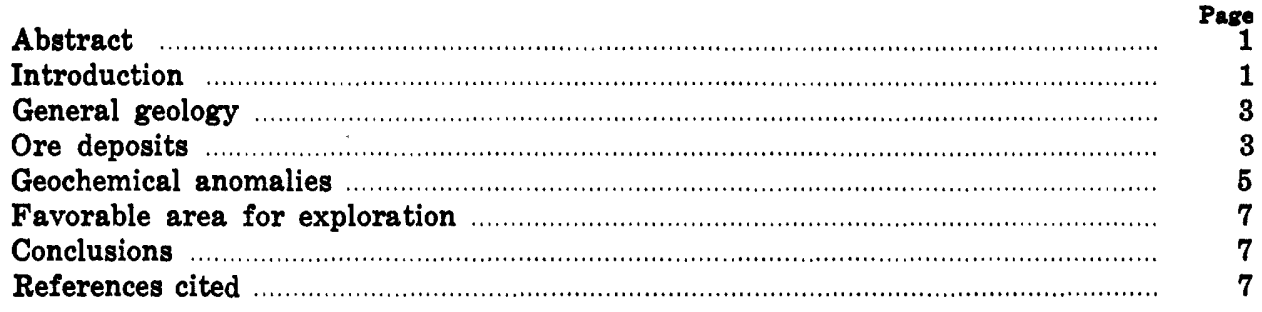

\section{ILLUSTRATIONS}

Figure 1. Index map showing location of Mill Canyon area

2. Map showing general geology of the Mill Canyon area, including mines, mineralized faults, and veins

3. Geologic map and sections of area near mouth of Mill Canyon

4-12. Maps showing element distribution:

4. Gold

5. Silver

6. Lead

7. Zinc

8. Copper

9. Arsenic

10. Antimony

11. Mercury

12. Tellurium

\section{TABLES}

TABLE 1. Range of values and median values of samples from the Mill Canyon area

2. Range of values and median values of samples collected for background values in the Cortez quadrangle 


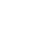




\title{
ANOMALOUS CONCENTRATIONS OF GOLD, SILVER, AND OTHER METALS IN THE MILL CANYON AREA, CORTEZ QUADRANGLE, EUREKA AND LANDER COUNTIES, NEVADA
}

\author{
By James E. ElliotT and John D. Wells
}

\begin{abstract}
The Mill Canyon area is in the eastern part of the Cortez window of the Roberts Mountains thrust belt in the Cortez quadrangle, north-central Nevada. Gold and silver ores have been mined from fissure veins in Jurassic quartz monzonite and in the bordering Wenban Limestone of Devonian age. Geochemical data show anomalies of gold, silver, lead, zinc, copper, arsenic, antimony, mercury, and tellurium. Geologic and geochemical studies indicate that a formation favorable for gold deposition, the Roberts Mountains Limestone of Silurian age, may be found at depth near the mouth of Mill Canyon.
\end{abstract}

\section{INTRODUCTION}

Many of the metallic ore deposits of northcentral Nevada occur in regional alinements or mineral belts. One of the most economically and geologically important, and also one of the most conspicuous, of these mineral belts is the northwest-trending Battle Mountain-Eureka belt (Roberts, 1966, p. 61), which includes the Cortez quadrangle. The dominant structural feature of north-central Nevada is the Roberts Mountains overthrust which juxtaposes Paleozoic siliceous and carbonate rocks of equivalent age. Many metallic mineral deposits are in lower plate carbonate rocks exposed in erosional windows of the Roberts Mountains thrust, such as the Cortez window. Several gold deposits occur in these lower plate carbonate rocks, particularly the Roberts Mountains Limestone of Silurian age, and in the breccia zones of the thrust. Examples of such deposits are the Carlin, Cortez, and Gold Acres mines (fig. 1) and the Bootstrap mine.

The U.S. Geological Survey has been conducting geologic and geochemical investigations under its Heavy Metals program in the Cortez quadrangle since July 1966. This report per- tains to the Mill Canyon area in the northeastern part of the Cortez quadrangle (fig. 1) in T. 27 N., R. 48 E., where lower plate Paleozoic carbonate rocks are intruded by Jurassic quartz monzonite. Preliminary results indicate that the relationships among gold and silver deposits, geochemical anomalies, and geologic features in the Mill Canyon area are favorable enough to warrant further investigation. The Roberts Mountains Limestone of Silurian age, present at a moderate depth below the surface near the mouth of Mill Canyon, and the zone of altered Wenban Limestone of Devonian age that borders the Mill Canyon stock are favorable hosts for gold deposits.

Geochemical investigations included collection and analysis of more than 300 rock samples. Sample localities are shown in the geochemical maps (figs. 4-12). All samples were from fault zones, veins, mine dumps, or outcrops of altered rock. More than one sample was collected from many of the localities shown, but only the highest value for each element from a given locality is plotted on the maps.

All samples were analyzed in the field in mobile laboratories of the U.S. Geological Survey. Gold and tellurium were determined by a wet chemical method using atomic absorption spectrophotometry. Mercury was determined instrumentally by an atomic absorption technique. Thirty elements were determined semiquantitatively on the emission spectrograph.

The geology of the Cortez quadrang? ${ }^{7} \mathrm{e}$ has been mapped and described by Gilluly and Masursky (1965). The economic geology of the area has been briefly described by Enmmons (1910) and Vanderburg (1938).

The authors acknowledge the assistarce, in analytical work, of G. H. VanSickle, D. J. Grimes, T. G. Ging, Jr., E. L. Mosier, and 


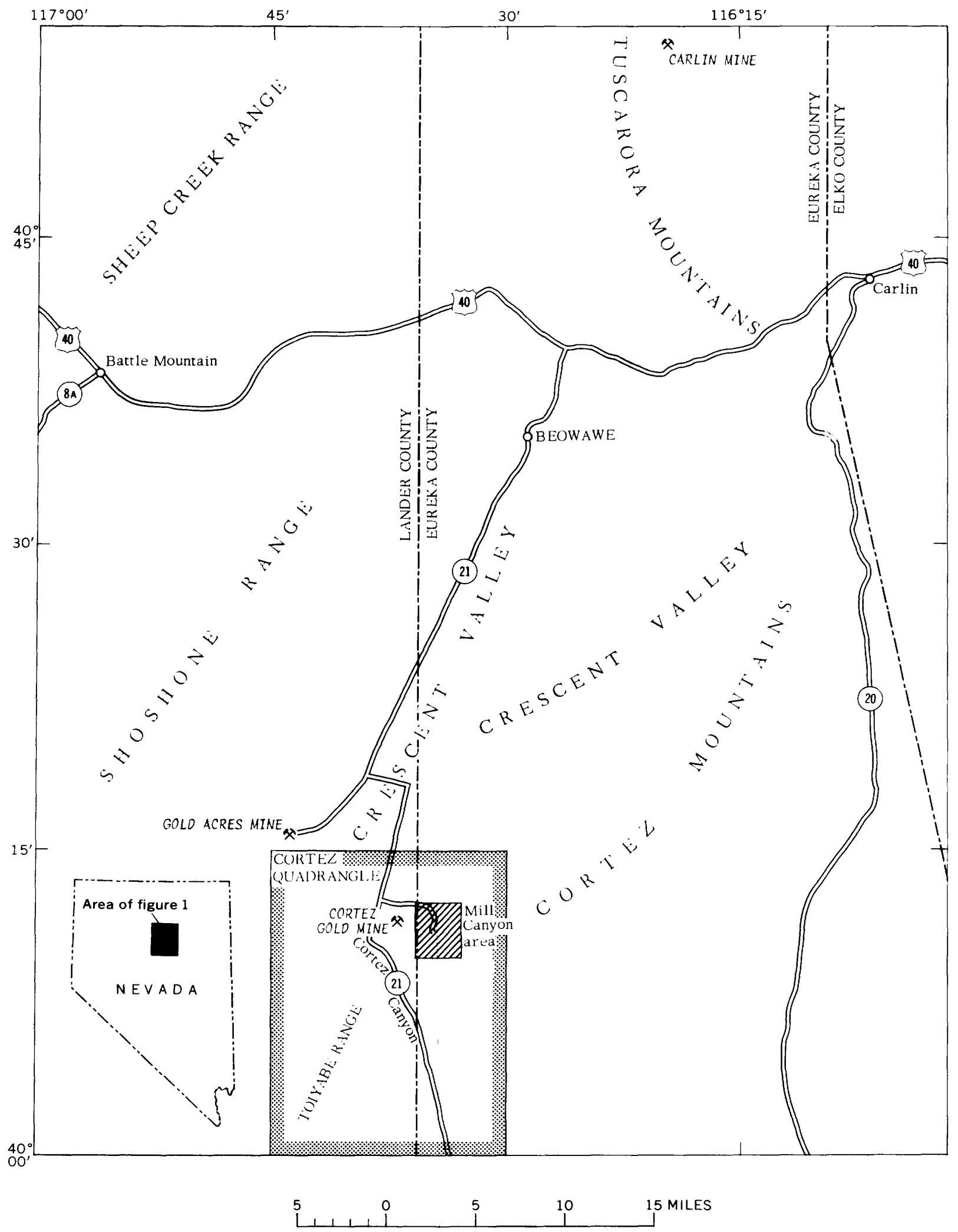

Figure 1.--Index map showing location of the Mill Canyon area in the Cortez quadrangle, anc Carlin, Gold Acres, and Cortez gold mines. Base from U.S. Geological Survey, Winnemucca quadrangle, 1:250,000, 1962. 
others of the Geological Survey. Also, the authors thank Mr. Allen Russell for permitting access to the mining properties in the Mill Canyon area and for many helpful discussions.

\section{GENERAL GEOLOGY}

The rocks of the Mill Canyon area include Paleozoic sedimentary rocks, intrusive rocks of Jurassic age, and Quaternary alluvial deposits (fig. 2). The Paleozoic sedimentary rocks comprise two distinct facies which are approximately equivalent in age; these facies are separated by the Roberts Mountains thrust fault. One facies includes formations that range in age from Cambrian to Devonian and consist predominantly of carbonate rocks with minor quartzite. The second facies includes formations that range in age from Ordovician to Silurian and consist predominantly of siliceous rocks. In adjacent areas, Devonian rocks of the siliceous facies are also represented. The carbonate facies is considered to be autochthonous and the siliceous facies allochthonous. The siliceous facies has been transported into juxtaposition with the carbonate facies from the west along the Roberts Mountains thrust (Gilluly and Masursky, 1965, p. 10). The rock unit mapped as Paleozoic undifferentiated occupies the thrust zone and is not directly assignable to either the carbonate or the siliceous facies.

Rocks of Jurassic age are the quartz monzonite of the Mill Canyon stock and the satellite bodies of alaskite and intermediate dikes associated with the stock. In figure 2, the igneous rocks are shown as one unit, and in figure 3 they are subdivided into quartz monzonite, alaskite, and intermediate dikes. A radiometric age determination by the potassium-argon method on a biotite concentrate from the Mill Canyon stock yielded an age of 151 million years (Gilluly and Masursky, 1965, p. 71).

In general, the sedimentary units strike north and dip moderately east. The Roberts Mountains thrust has been warped into an antiform (Gilluly and Masursky, 1965, p. 89), and later erosion has formed the Cortez window in which the carbonate facies is exposed below the thrust. The lower plate rocks are cut by many faults, most of which are probably related to the period of thrusting. The upper plate is structurally more complex and is composed of many slices of western facies, all faulted together with little apparent system (Gilluly and Masursky, 1965, p. 93).

The Mill Canyon stock intrudes the lower plate rocks in the axis of the Cortez window and crosscuts the Roberts Mountains thrust to the east. The stock is composite and consists of two parts: (1) a discordant western part, roughly rectangular in outline, and (2) ar eastern laccolithic or bysmalithic lobe (Gilluly and Masursky, 1965, p. 68). Several mineralized veins are near the junction of the two parts of the Mill Canyon stock (fig. 2, left of center).

\section{ORE DEPOSITS}

Deposits in the Mill Canyon area have been prospected and mined for the past 100 years. The estimated total production from the area is approximately $\$ 800,000$. Vanderburg (1938, p. 26) estimated the total production prior to 1937 at $\$ 200,000$. The remaining $\$ 500,000$ was produced mostly in the years 1937-42 (U.S. Bureau of Mines, 1938-59). Most of the mining has been in gold and silver, the gold predominating in dollar value. The ore deposits are of three types: (1) fissure veins in quartz monzonite that contain silver, lead, zinc, anc gold, (2) silver, lead, and zinc replacement deposits in limestone (Vanderburg, 1938, p. 27), and (3) gold deposits along fault zones in limestone. The most productive deposits have been nearsurface oxidized ore along faults in limestone near the quartz monzonite-limestone ccntact.

Several of the more important mines and workings and the mineralized faults and veins are shown in figure 2. Few of the mine workings are now accessible. In the quartz monzonite the main ore-bearing structures trend north-northeast to north-northwest and dip steeply. Near the southern border of the stock, at the Emma $\mathrm{E}$ mine (the southernmost mine shown in fig. 2), the main fault strikes northwest and dips $50^{\circ}-75^{\circ} \mathrm{NE}$. Near the northern border of the stock, deposits in the Wenban Limestone are along extensions of the northnortheast and north-northwest trends and along faults which are parallel to the instrusive contact (fig. 3). These faults generally trend east to northeast and $\operatorname{dip} 35^{\circ}-40^{\circ} \mathrm{N}$. or $\mathrm{NW}$. 


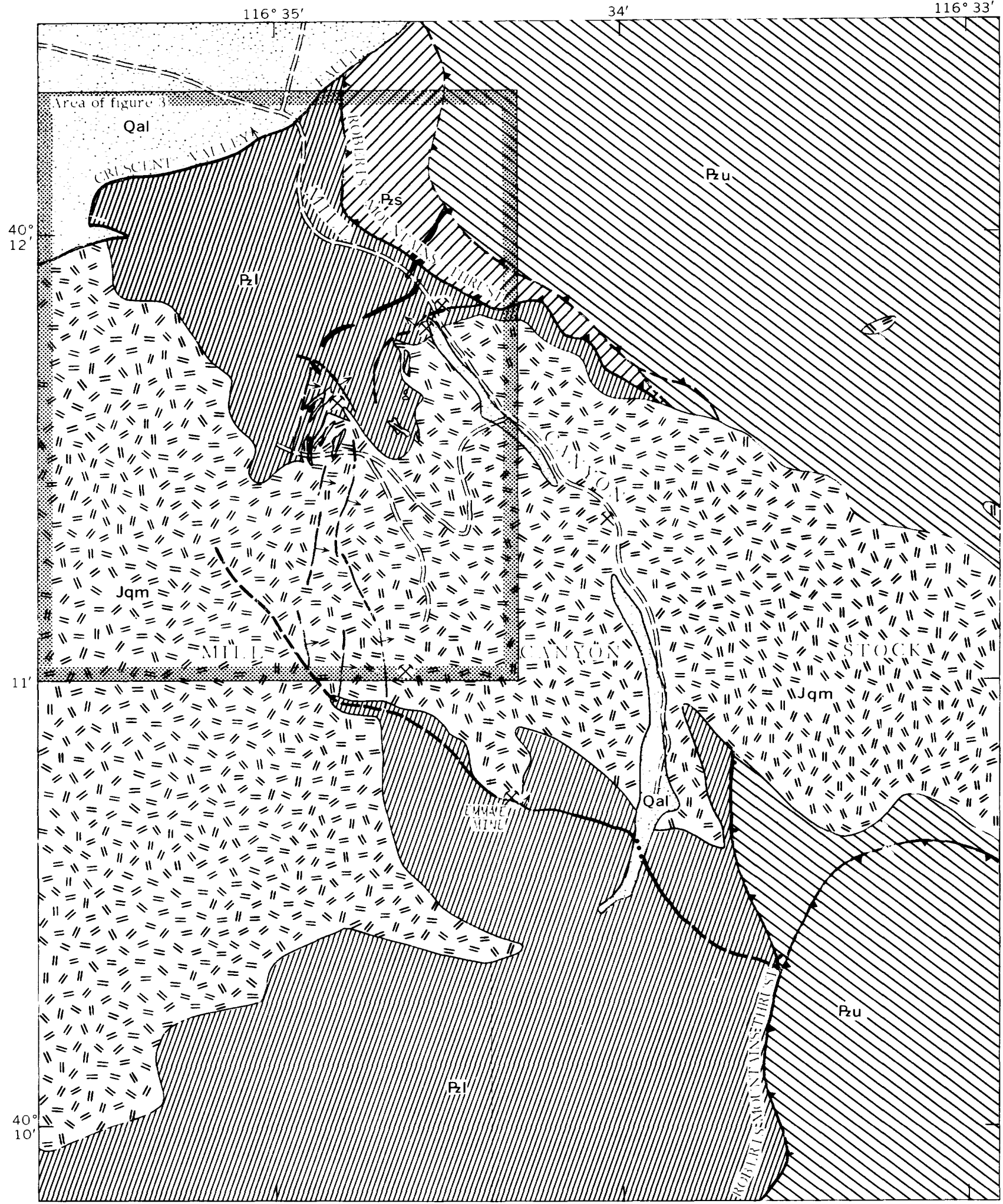

2000 i

Figure 2.-General geology of the Mill Canyon area. Geology by Gilluly and Masursky (1965); modified by Elliott. 


\section{EXPLANATION}

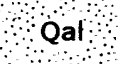

Quaternary alluvium

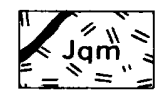

Jurassic quartz monzonite, alaskite, and inter mediate dikes

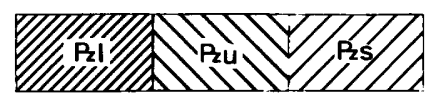

Paleozoic sedimentary rocks $\mathbf{P}_{\mathbf{Z}}$, lower plate carbonate facies

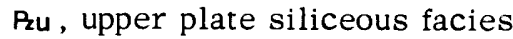
Ps, undifferentiated

\section{Contact}

Dashed where approximately located

High-angle fault, showing direction of dip. Dashed where approximately located; dotted where concealed

Thrust fault, sawteeth on upper plate. Dashed where approximately located

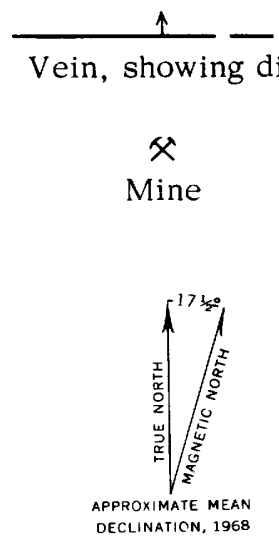

Figure 2.-Continued.
The mineralogy and mineral associations of the gold-silver ores were studied in 38 polished sections of ore specimens. The specimens were obtained mainly from unoxidized vein material on mine dumps. The predominant primary sulfide minerals are pyrite, arsenopyrite, sphalerite, and galena. Boulangerite, bournonite, argentian tetrahedrite, chalcopyrite, pyrargyrite-proustite, gold, and stibnite commonly occur in minor amounts. Vanderburg (1938, p. 27) noted the occurrence of argentite and stephanite also. Arsenic and antimony are generally abundant in the ores. Tellurium and mercury are present in anomalous concentrations.

One of the main purposes of this study ras to determine the sites and modes of occurrence of the gold and silver. Most of the silver is in argentian tetrahedrite; some occurs as ruby silver minerals. Silver-rich samples usually contain abundant sulfosalts of lead, copror, silver, and antimony, such as boulangerite, bournonite, tetrahedrite, and ruby silver minerals. Gold, where seen in polished sections, occurs as blebs (5-40 microns across) in pyrite or, rarely, in arsenopyrite. Amounts of gold and silver vary somewhat independently and may reflect different phases of mineralization.

\section{GEOCHEMICAL ANOMALIES}

The Mill Canyon area contains anomalous amounts of gold, silver, lead, zinc, copr $r$, arsenic, antimony, mercury, and tellurium (figs. 4-12). Locally, anomalous amounts of other elements are present. The highest anc $m$ alies lie in a northwest-trending belt and occur in the quartz monzonite and the adjoining Wenban Limestone of Devonian age. The anomalies in the quartz monzonite are concentrated alc ng north-trending fissure veins where the east lobe and the west part of the stock join. The anon?alies in the Wenban Limestone are concentrated in faults and altered zones. Although most of the mineralized Wenban Limestone is near the contact of the quartz monzonite, some of the mineralized limestone occurs near the Roberts Mountains thrust near the mouth of Mill Canyon.

A summary of data (table 1) shows the range of values and median values for most of 
the samples from the Mill Canyon area. Table 2 presents analyses of samples selected in the Cortez quadrangle from apparently unaltered country rocks to obtain background values for gold, silver, lead, zinc, copper, arsenic, antimony, and mercury. No background data are available for tellurium. Of the background samples, 11 were from quartz monozite and alaskite, 38 from lower plate rocks, and 20 from upper plate rocks. The high concentration of all metals in the Mill Canyon area is striking when compared to the background values.

The analytical results pertaining to the Mill Canyon samples were treated statistically. A most valuable statistical treatment, for the purposes of this study, is that of correlation analysis, which measures the degree of similarity between different pairs of variables, such as between gold and silver or between lead and and zinc. The correlation coefficient may range from -1.0 , a perfect negative correlation, to +1.0 , a perfect positive correlation. A high negative correlation signifies that as one element (for example, gold) increases, another element (for example, silver) decreases proportionately or vice versa. A high positive correlation indicates that both elements increase or decrease proportionately. A low positive or negative correlation coefficient-one that ap-

TABLE 1.-Range of values and median values, in parts per million, of samples from the Mill Canyon area

\begin{tabular}{|c|c|c|c|c|c|}
\hline & Element & Minimum & Maximum & Median & No. of samples \\
\hline $\begin{array}{l}\mathrm{Au} \\
\mathrm{Ag} \\
\mathbf{P b} \\
\mathrm{Zn} \\
\mathrm{Cu} \\
\mathrm{As} \\
\mathrm{Sb} \\
\mathrm{Hg} \\
\mathrm{Te}\end{array}$ & 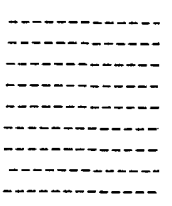 & $\begin{array}{c}<0.1 \\
<.5 \\
<200 \\
<2 \\
<200 \\
<100 \\
<.05\end{array}$ & $\begin{array}{r}160 \\
5,000 \\
>10,000 \\
>10,000 \\
>5,000 \\
>10,000 \\
>10,000 \\
>10 \\
62\end{array}$ & $\begin{array}{r}<0.1 \\
1.5 \\
25 \\
<200 \\
60 \\
600 \\
100 \\
.5 \\
.1\end{array}$ & $\begin{array}{l}273 \\
273 \\
273 \\
273 \\
273 \\
273 \\
273 \\
273 \\
305\end{array}$ \\
\hline
\end{tabular}

TABLE 2.-Range of values and median values, in parts per million, of samples collected for background values in the Cortez quadrangle

\begin{tabular}{|c|c|c|c|c|c|}
\hline & Element & Minimum & Maximum & Median & No. of samples \\
\hline $\begin{array}{l}\mathrm{Au} \\
\mathbf{A g} \\
\mathbf{P b} \\
\mathbf{Z n} \\
\mathbf{C u} \\
\mathrm{As} \\
\mathbf{S b} \\
\mathbf{H g}\end{array}$ & בים & $\begin{aligned} &<0.02 \\
&<.5<10 \\
&<200 \\
&<5 \\
&<200 \\
&<100 \\
&<.01\end{aligned}$ & $\begin{array}{r}0.1 \\
5 \\
100 \\
\mathbf{3 0 0} \\
\mathbf{3 0 0} \\
<200 \\
\quad \mathbf{3 0 0} \\
\quad .95\end{array}$ & $\begin{array}{c}<0.02 \\
10 \\
<200 \\
10 \\
<200 \\
<100.10\end{array}$ & $\begin{array}{l}69 \\
65 \\
63 \\
69 \\
69 \\
69 \\
69 \\
56\end{array}$ \\
\hline
\end{tabular}

proaches zero-shows that the two elements act fairly independently of each other.

Correlation analysis was applied to geochemical samples collected in the Mill Canyon area to test the relations among anomalous elements and to test the use of certain elements as indicators of mineralization.

As a first test, 106 samples from veins and fault zones in the quartz monzonite stock were compared. The results showed strong positive correlations between the element pairs: goldlead, gold-copper, gold-antimony, gold-iron, silver-lead, silver-antimony, silver-copper, silver-iron, lead-copper, lead-antimory, lead-iron, copper-antimony, copper-iron, and antimonyiron. The element pair gold-silver had a low positive correlation. Little or no correlation was indicated for all other possible element pairs.

In a second test, 273 samples ccllected from all rock units in the Mill Canyon area were compared. Relationships established for samples from the quartz monzonite stork thus were tested for the area as a whole. E'ment pairs showing strong positive correlatiors were goldarsenic, silver-lead, silver-copper, silver-antimony, lead-copper, lead-antimony, and copperantimony. The element pair gold-silver had a very low positive correlation. All other element pairs showed little or no correlation.

The strong positive correlations for samples from the quartz monzonite stock involving gold as one element of the element pair did not hold true for the area as a whole, whereas most of the strong correlations involving silver did hold true. The results of the statistical treatment support the geologic evidence from the study of polished sections. The conclusions are:

1. Silver is found in sulfosalt suites of silver-, lead-, antimony-, and copper-baaring minerals, such as tetrahedrite, lsulangerite, bournonite, and ruby silvers or oxidized equivalents of these suites, both. in the Mill Canyon stock and in the bordering rocks.

2. In the igneous rocks, gold also occurs with the sulfosalt suite of minerals and is associated with iron in pyrite. However, the behavior of gold with respect to silver is erratic.

3. In samples taken from all rock types, gold is somewhat erratic and shows a preference only for arsenic, perhaps reflecting an association with arsenopyrite. 
Geochemically the best indicator elements for gold and silver are: (1) lead, copper, and antimony for gold and silver in the quartz monzonite stock, (2) lead, copper, and antimony for silver in the bordering country rocks, and (3) arsenic for gold in the bordering country rocks. Locally, however, other elements, such as mercury or tellurium, may be important indicators of gold and silver deposits.

\section{FAVORABLE AREA FOR EXPLORATION}

The most favorable area for exploration is a roughly rectangular block of Wenban Limestone, locally mineralized and altered, near the mouth of Mill Canyon. The area is bordered on the west and south by quartz monzonite, on the east by the Roberts Mountains thrust, and on the northwest by the Crescent Valley fault (fig. 3). Lithologically this block of limestone is similar to the lower 1,000 feet of Wenban Limestone at the type section, 4 miles to the southwest in Cortez Canyon. Early Devonian fossils have been collected from the upper part of this block near the mouth of Mill Canyon (Gilluly and Masursky, 1965, p. 32). The limestone has been bleached and partly silicified for as much as 1,000 feet from the intrusive contact. The bleaching has changed the normal medium gray or dark gray of the limestone to a light buff. Locally, extreme silicification has resulted in the formation of dense brown jasperiod. Geochemically this area is anomalous in gold, silver, lead, zinc, copper, arsenic, antimony, mercury, and tellurium, especially near the instrusive contact.

Inasmuch as some of the major gold deposits in north-central Nevada occur in the Roberts Mountains Limestone, the same rocks should be considered in the Mill Canyon area as a favorable host for gold deposits. The new Cortez gold discovery is only $11 / 2$ miles to the west of Mill Canyon. The gold at this locality is concentrated in the Roberts Mountains Limestone just below the Wenban Limestone and is associated with anomalies of mercury, arsenic, antimony, and tungsten (Wells and others, 1967). These elements, with the exception of tungsten, also occur in anomalous concentrations in the northwestern part of the Mill Canyon area.
The Roberts Mountains Limestone is not exposed at the surface near the mouth of Mill Canyon but would be expected to occur at a shallow depth. Cross sections in figure 3 show the interpreted subsurface geology near the mouth of Mill Canyon. From these cross sections, the Roberts Mountains Limestone is estimated to be 300-1,500 feet below the surface. Favorable zones for gold deposits may be present near the intersection of projected vein structures and the Roberts Mountains-Wenban contact.

The geochemical association of metals in the zone of alteration in the Wenban Limertone adjacent to the Mill Canyon stock is also similar to that in the Cortez deposit. This similarity suggests that physical exploration for ar economic evaluation of this area is justified.

\section{CONCLUSIONS}

Geologic studies show the Mill Canyon area to be mineralized and to have a geochemic l association of metals that is similar to the associations in the Cortez, Carlin, and other gold mines in north-central Nevada. Potential mineralized rock is untested at depth, but on the basis of this evidence some exploration vould appear justified. In particular, the Roherts Mountains Limestone is favorable to test and sample because of its known association with gold deposits in this area.

\section{REFERENCES CITED}

Emmons, W. H., 1910, A reconnaissance of some mining camps in Elko, Lander, and Eureka counties, Nevada: U.S. Geol. Survey Bull. 408, $130 \mathrm{p}$.

Gilluly, James, and Masursky, Harold, 1965, Geology of the Cortez quadrangle, Nevada, with a section on Gravity and aeromagnetic surveys, by D. R. Mabey: U.S. Geol. Survey Bull. 1175, 117 p.

Roberts, R. J., 1966, Metallogenic provinces and mineral belts in Nevada, in AIME Pacific Southwest Mineral Industry Conf., Sparks, Nev., 1965: Nevada Bur. Mines Rept. 13, Papers, pt. A, p. 47-72.

U.S. Bureau of Mines, 1938-59, Minerals yearbook [annual volumes for years 1937-58]: Washington, U.S. Govt. Printing Office. 
Vanderburg, W. O., 1938, Reconnaissance of mining districts in Eureka County, Nevada: U.S. Bur. Mines Inf. Circ. 7022, 66 p.
Wells, J. D., Erickson, Ralph, and Stoiser, L. R., 1967, Geology and mineralogy of the Cortez gold deposit, Nevada [abs.]: Mining Eng., v. 19 , no. 12 , p. 40 . 
7I-8 SНชดつIН 


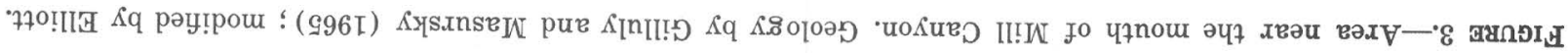

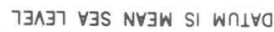

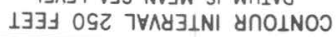

$1 \exists \exists \exists 0002$

000T

0

OOOI

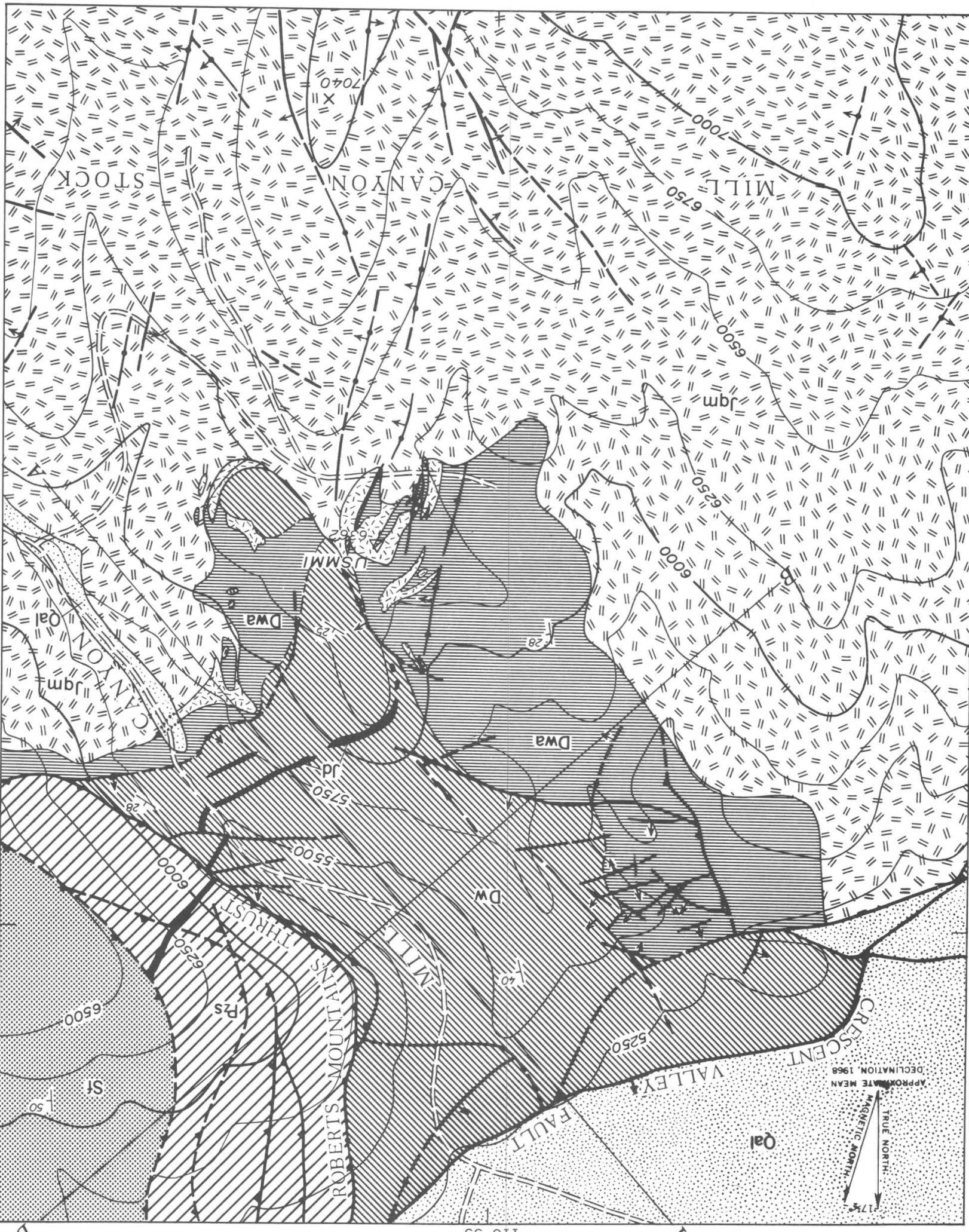


$\because$ Qail

Quaternary alluvium

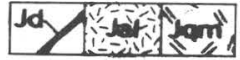

Jurassic intrusive rocks

d, intermediate dikes

Jal, alaskite

Jam, quartz monzonite

\section{Dw}

Devonian Wenban Limestone

Dwa, altered

\section{Srivi.}

Silurian Roberts

Mountains Limestone

\section{\%女s}

Silurian Fourmile

Canyon Formation

\section{照思}

Paleozoic rocks

undifferentiated
Contact

Dashed where approximately located; dotted where concealed

High-angle fault, showing direction of dip. Dashed where approximately located

Thrust fault, sawteeth on upper plate. Dashed where approximately located

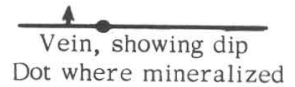

\section{Strike and dip of beds}

(1)

Probable extension of vein

From surface and underground workings. Shown on section $\mathrm{A}-\mathrm{A}$ 'only
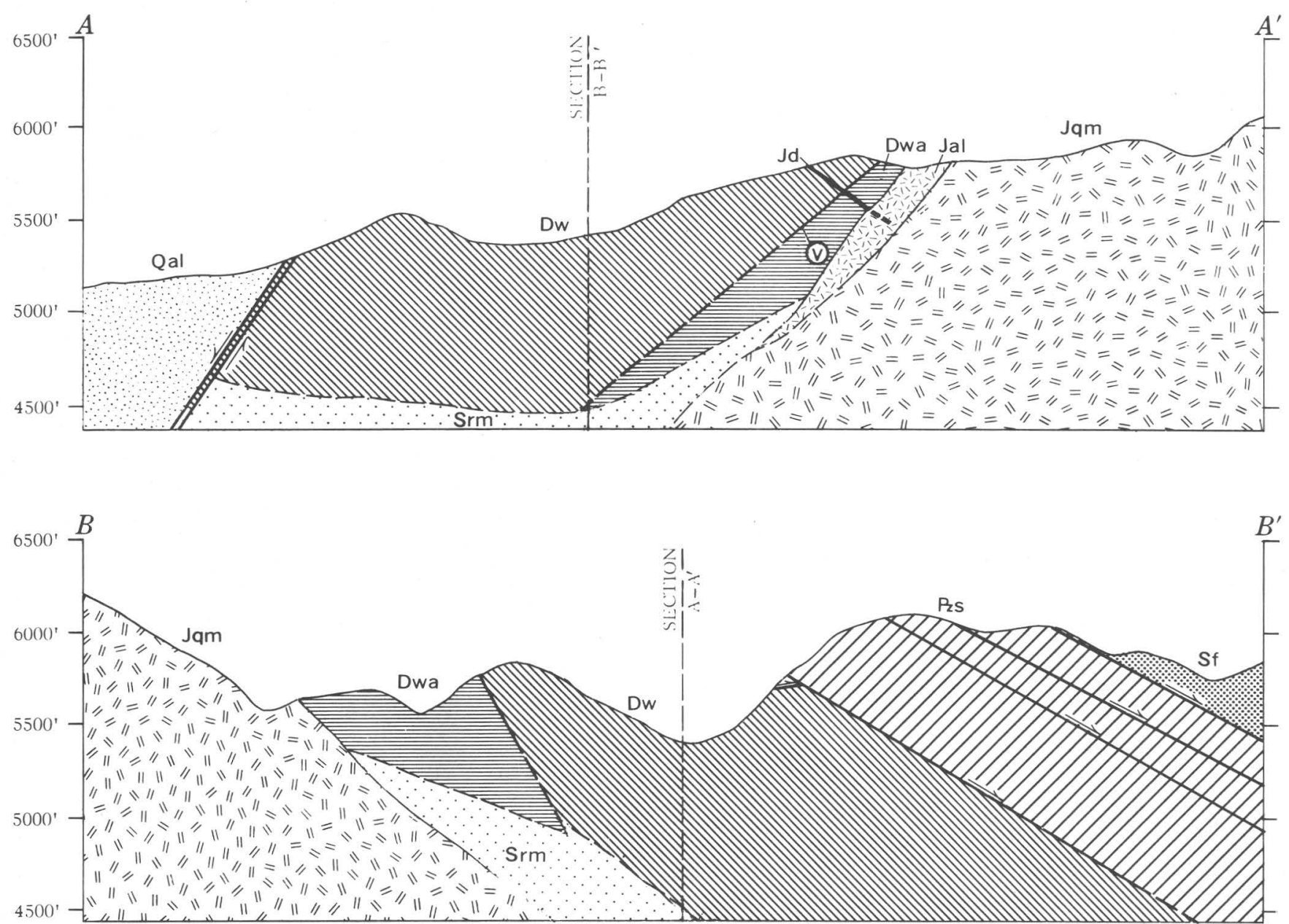


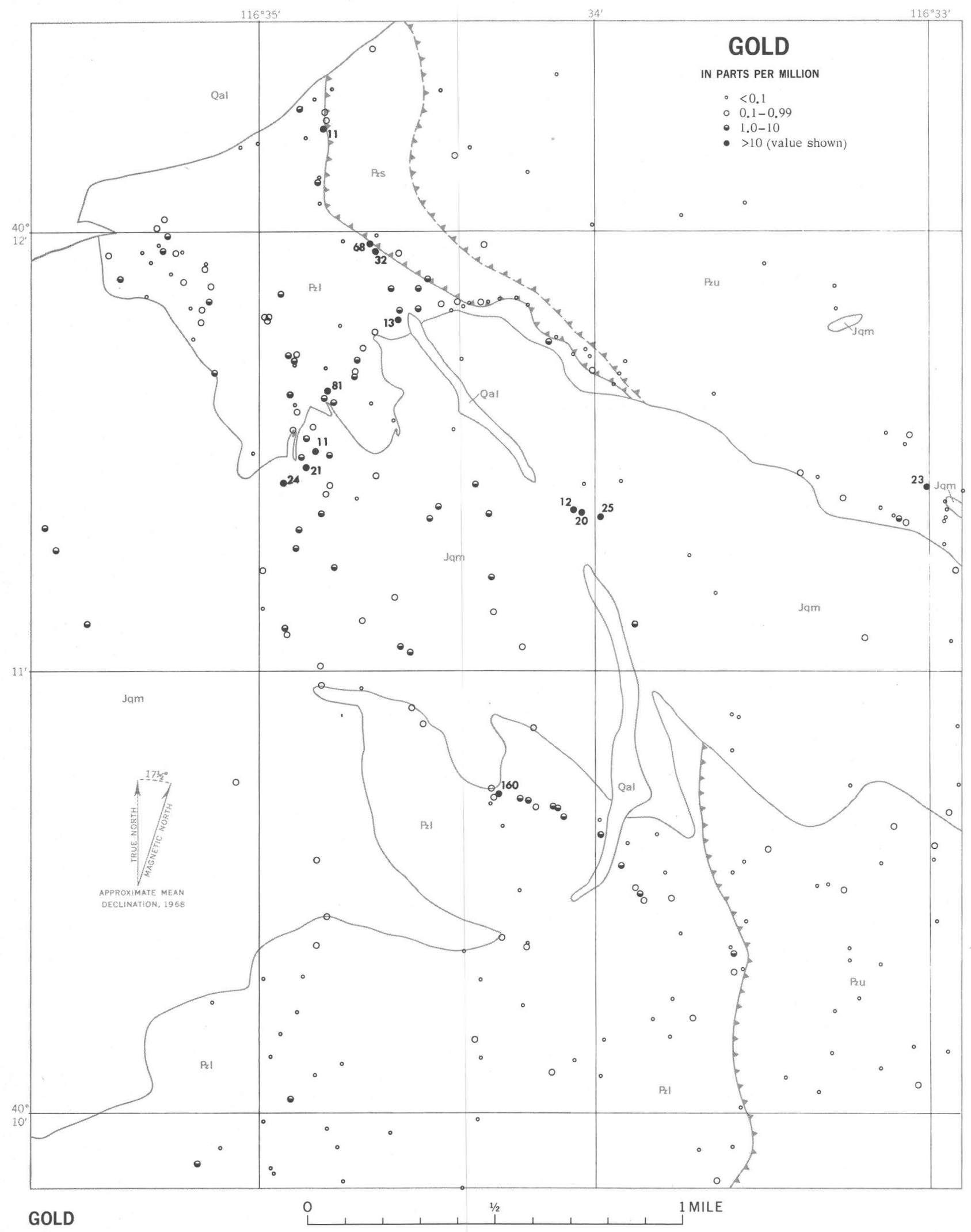

FIGURE 4.-Gold distribution, maximum concentration in all samples at each locality. Geologic symbols explained in figure 2. 


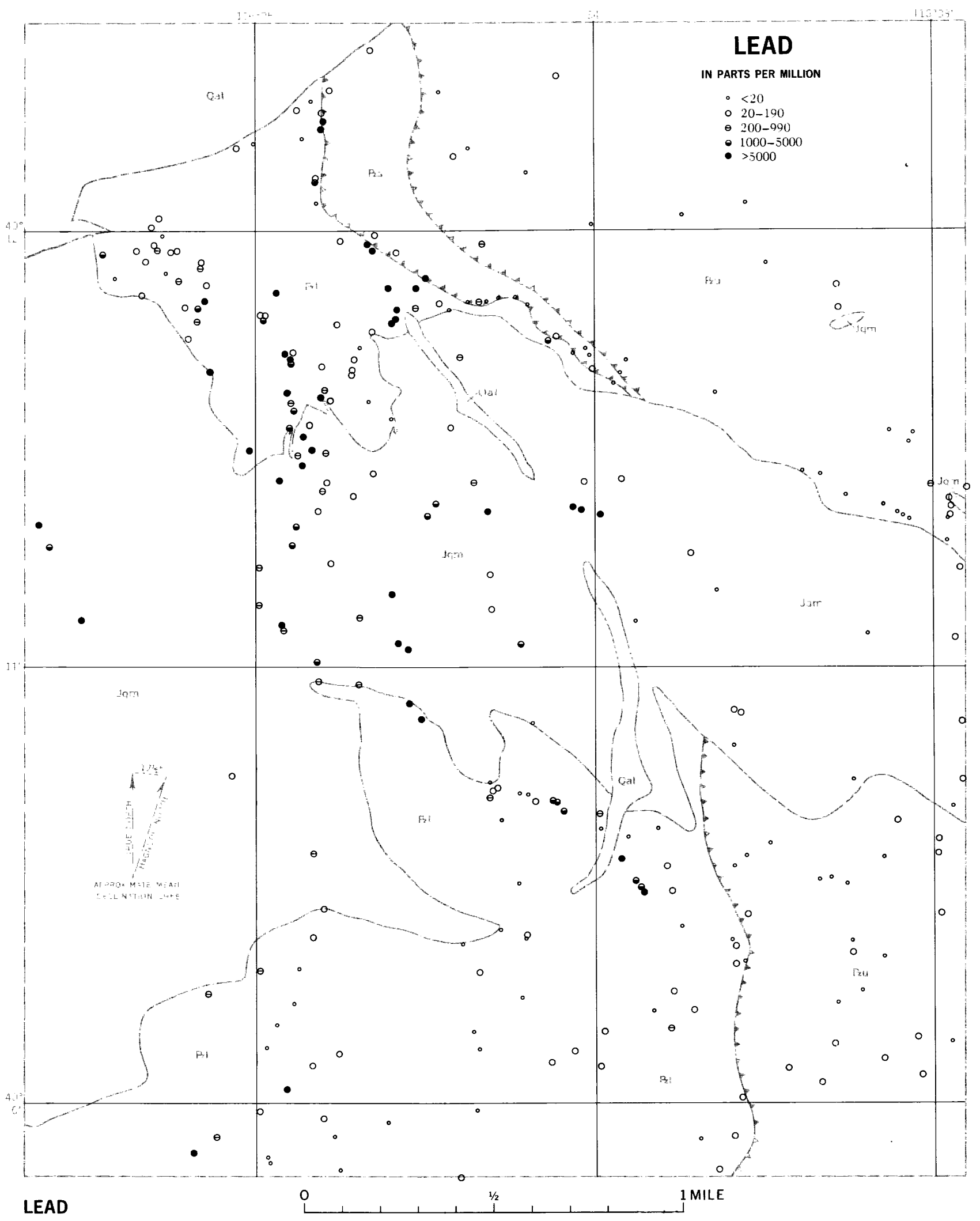

Figure 6.-Lead distribution, maximum concentration in all samples at each locality. Geologic symbols explained in figure 2 . 


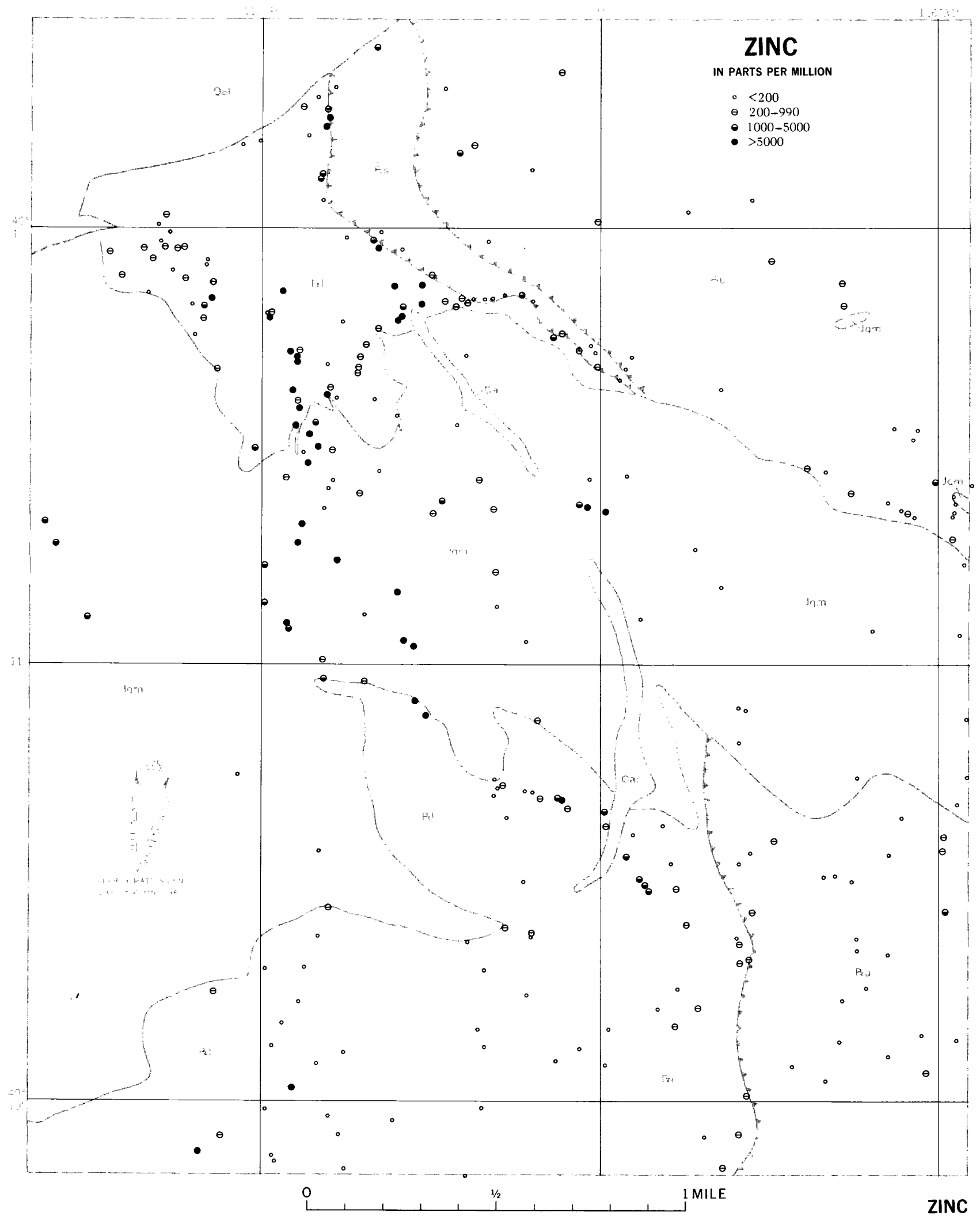

Figure 7.-Zinc distribution, maximum concentration in all samples at each locality. Geologic symbols explained in figure 2. 


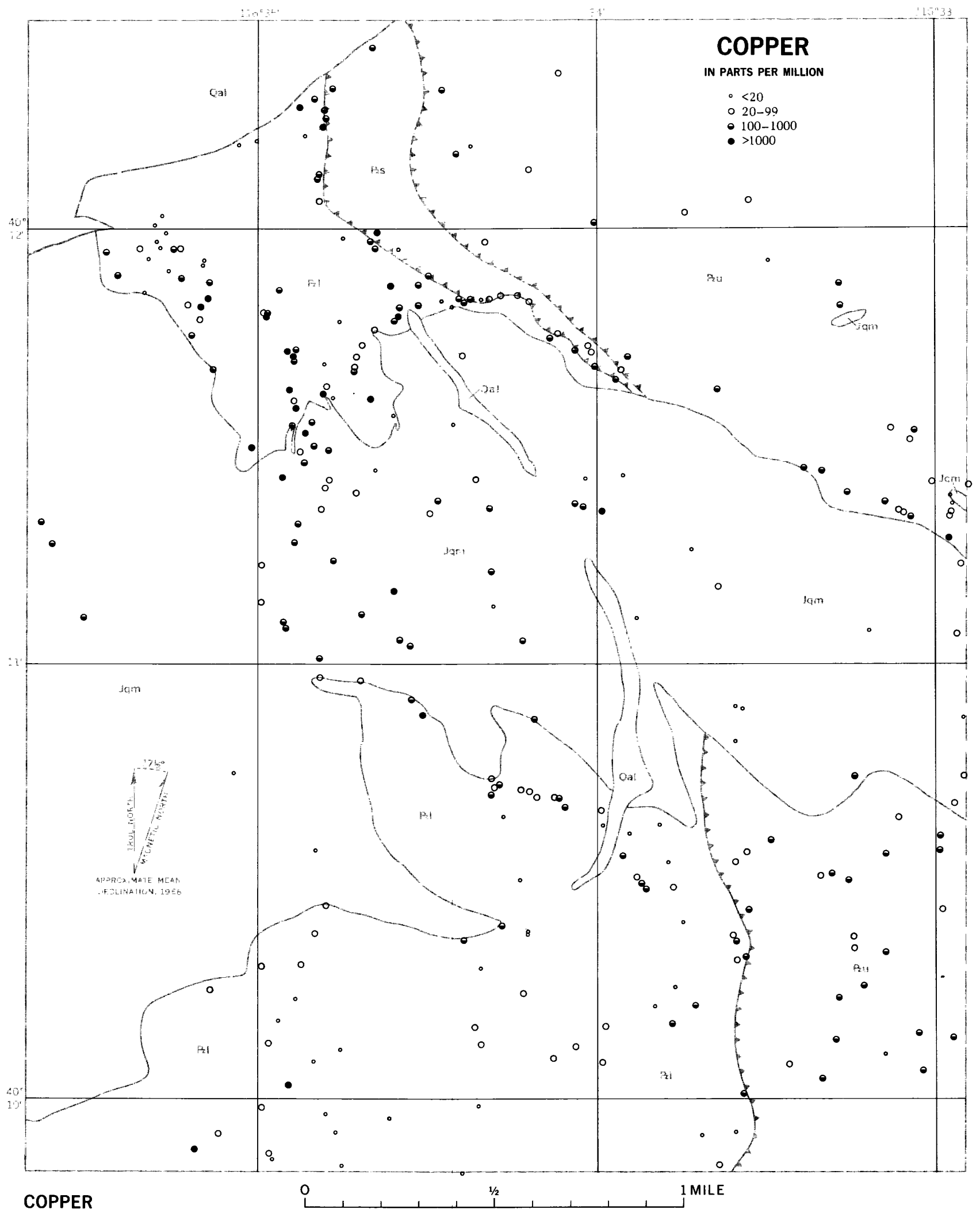

Figure 8.-Copper distribution, maximum concentration in all samples at each locality. Geo'ngic symbols explained in figure 2. 


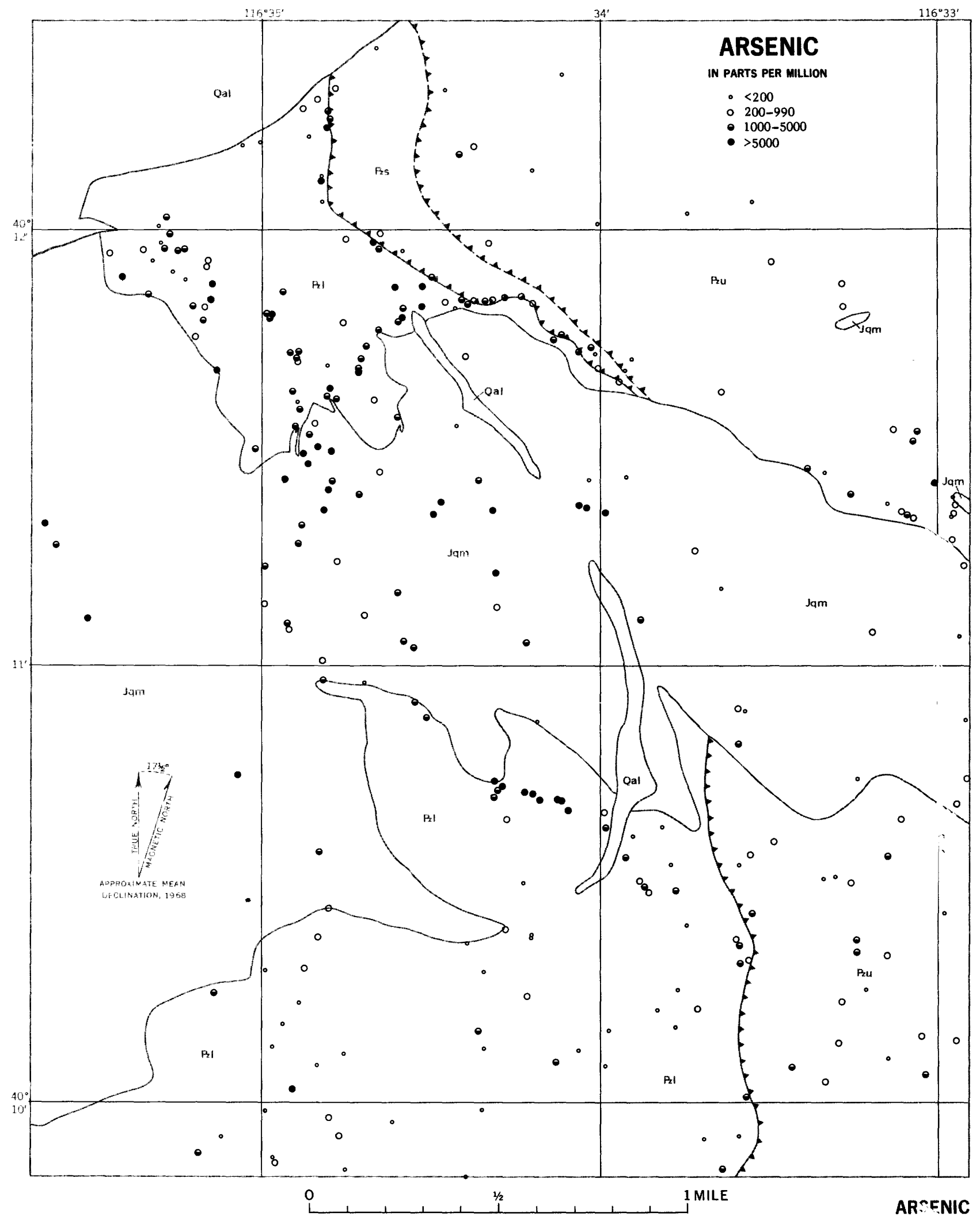

Figure 9.-Arsenic distribution, maximum concentration in all samples at each locality. Geologic symbols explained in figure 2. 


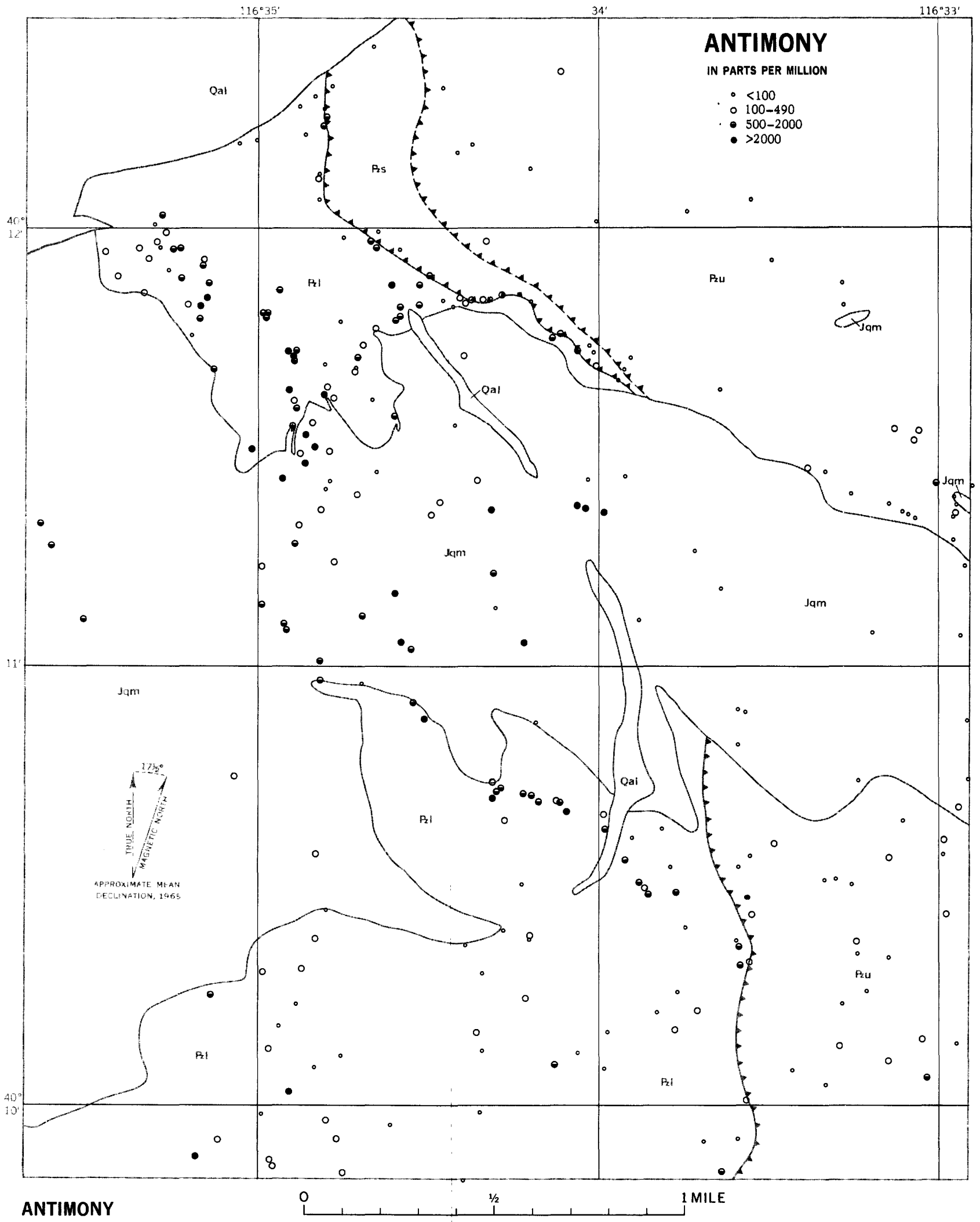

FIGURE 10. -Antimony distribution, maximum concentration in all samples at each locality. Geologic symbols explained in figure 2 .

18 


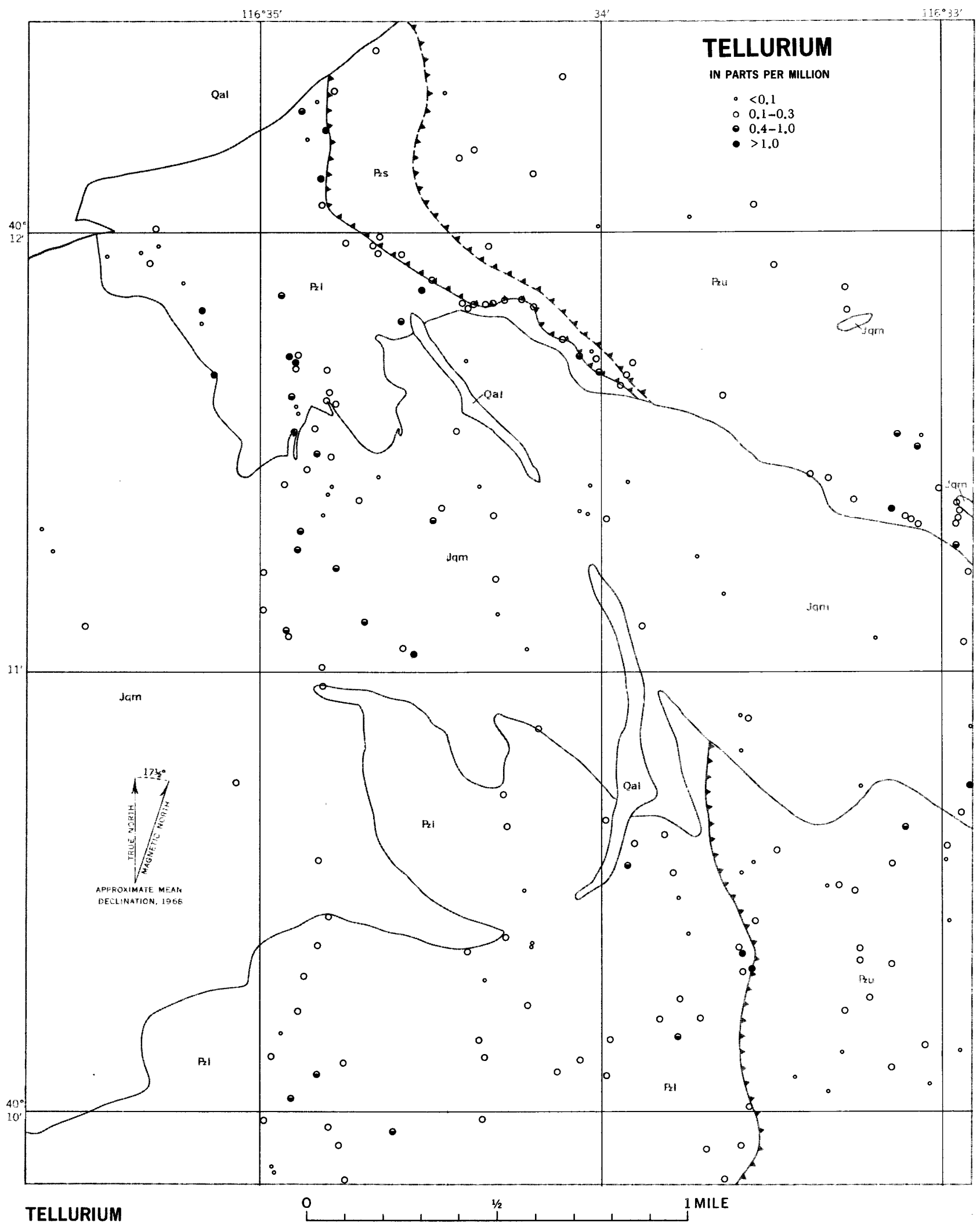

FIGURE 12.-Tellurium distribution, maximum concentration in all samples at each locality. Geologic symbols explained in figure 2 . 